\title{
GENETIC DIFFERENTIATION OF THE KAMPAR RIVER'S GIANT FEATHERBACK (Chitala lopis BLEEKER 1851) BASE ON MITOCHONDRIAL DNA ANALYSIS
}

\author{
Arif Wibowo ${ }^{1)}$, Ridwan Affandi' ${ }^{2)}$, Kadarwan Soewardi ${ }^{2)}$, and Sudarto ${ }^{3)}$ \\ ${ }^{1)}$ Researcher at Research Institute for Inland Waters Fisheries, Mariana-Palembang \\ 2) Lecturer in Faculty of Fisheries and Marine Science, Bogor Agricultural University, Bogor \\ ${ }^{3}$ Researcher at Research Institute of Cultured Ornamental Fish-Depok \\ Received July 6-2010; Received in revised form September 1-2010; Accepted November 2-2010
}

\begin{abstract}
Although the giant featherback Chitala lopis is an important fish in Kampar River, the population structure has not been investigated. In this study, genetic diversity and population structure of giant featherback were examined using nucleotide sequence analysis of mitochondrial DNA control region for 54 fish collected from Kampar River. As a comparison, samples from Barito River (South Kalimantan Province), Penyak River (Bangka-Belitung Province), and Indragiri Hilir (Riau Province) were also used in this analysis. The Kuala Tolam (lower reaches of Kampar River) samples had higher nucleotide diversity (ð) (0.0033) than Kutopanjang Reservoir (0.0011) and Teso (0.00) (upper reaches of Kampar River), the nucleotide diversity all samples varied from $0.000-0.0033$. The genetic differentiation and genetic structure among Kampar River's giant featherback were also supported by pairwise F-statistic value and hierachical analysis of molecular variance, indicating that the Kuala Tolam population is genetically isolated from the population in upper reaches of Kampar River.
\end{abstract}

KEYWORDS: giant featherback, control region, mitochondrial DNA, genetic variation, Kampar River

\section{INTRODUCTION}

Indonesian giant featherback is a member of Notopteridae family (Kottelat et al., 1993; 1997), which has economic value and culture. This fish is very popular because its meat has delicious taste and distinctive primarily because of high fat content (Sunarno, 2002), as well as protein content and high vitamin $\mathrm{A}(\mathrm{MnO}, 2005)$, placing giant featherback as exclusive and expensive freshwater fish with enough price (more than Rp.50 000/kg). As an illustration, the demand for giant featherback homemade industry of about $200 \mathrm{~kg} /$ day and used for ornamental fish and the consumption of $40 \mathrm{~kg} / \mathrm{day}$. While fishermen just only supply less than $2 \%$ (Anonymous, 2003).

Giant featherback fish production decreased due to the fishing activities for consumption and ornamental fish uses. Giant featherback annual production has been declined, both at the national level (8,000 tonnes (1991), 5,000 tons (1995), and 3,000 tons (1998) (Directorate General of Fisheries, 2000)), and regionally (Sungai Kampar, Province Riau). The annual production of giant featherback in the Kampar River has been decreased, from 50.2 tons (in 2003) to 7.6 tons in 2007 (Agency of Marine and Fisheries, 2008). This condition seems to be continued since the demand of this fish is continuously for human need. Consequently, the giant featherback species would be edangerous, while few information is available on the genetic variation and population differences among giant featherback populations.
Actually, almost all genetic studies of giant featherback were based on morphological characteristics (Sunarno et al., 2007; Wibowo, 2008a) with the exception of Madang (1999) and Wibowo (2008b), which simply studying giant featherback genetic. There were no researches related to the variation of giant featherback populations in large geographic areas (along river), a more detailed level, sequense DNA.

Knowledge of genetic population is important in planning and implementing appropriate management strategies for the giant fetaherback that is more and more endangered. Furthermore, efforts regarding to reduce pressures on natural populations through domestication and increase production through selective breeding, the basic information related to genetic conditions of this species is neccessary. Here, the genetic differences in geography are analyzed to provide a clear picture of the structure of giantfeatherback populations in Kampar River, Riau Province. The results can provide important biological information as basic information, necessary to plan proper policy and management of giant featherback in the Kampar River.

\section{MATERIALS AND METHODS}

\section{Fish Samples}

Total of 51 individuals were collected from five locations in Kampar River, details of each location 
and genetic data show in Table 1. As a comparison, samples from Barito River (South Kalimantan Province), Penyak River (Bangka-Belitung Province) and Indragiri Hilir (Riau Province) were also used in this analysis ( 3 individuals). Blood was taken from all giant featherback individual and stored in absolute alcohol $99.5 \%$ until the DNA extraction process.

\section{DNA Extraction, PCR Amplification, and Sequencing}

DNA extraction and PCR amplification were done at Laboratory of Molecular Biology, Faculty of Science, Bogor Agricultural University, Bogor. Total genomic DNA extracted from giant featherback blood which has been previously stored in absolute ethanol, using genomic extraction kit GENEAID. DNA was purified, and then dried in $100 \mathrm{uL}$ dissolve in the elusion buffer and stored in refrigerator $-20^{\circ} \mathrm{C}$.

Some regions of mtDNA control region fragment were amplified using species specific primers of $L-15$ 940-Thr (5'-AAGG TGTAATCCGAAGATTG-3') and CRH (5-TAACGAACTTATGTACGACG-3) (Takagi et al., 2006). PCR performed with a thermal cycler BIOER. 30uL PCR reaction mix containing 1.2 units of Tag DNA polymerase (Kappa), 1 x reaction buffer, $5 \mathrm{mM}$ $\mathrm{MgCl}_{2}, 0.4 \mu \mathrm{M}$ primer, $250 \mu \mathrm{M}$ dNTPs, and $50 \mathrm{ng}$ genomic DNA. PCR cycles included a pre-condition of 3 min denaturation at $94^{\circ} \mathrm{C}$ and 28 cycles of $15 \mathrm{sec}$ $94^{\circ} \mathrm{C}, 15 \mathrm{sec} 70 \mathrm{sec}$ at $48^{\circ} \mathrm{C}$ and $68^{\circ} \mathrm{C}$, followed by final extension for $5 \mathrm{~min}$ at $72^{\circ} \mathrm{C}$. PCR product then sent to DNA sequencing services, 1st Base, Singapore for the sequencing. In each sample, sequence done in both directions (forward and reverse), so there are total 108 single-pas DNA sequences fitted for 54 individuals.

\section{Data Analysis}

Sequence chromatograms displayed and edited manually using BIOEDIT (Applied Biosystems, Foster City, CA, USA). After the editing process, multiple allignment was carried out using CLUSTAL X 1.81 (Thompson et al., 1997). Haplotype diversity (h) (Nei \& Tajima, 1981), nucleotide diversity (ð) (Nei, 1987), Analysis of Molecular Variance (AMOVA) (Excoffier et al., 1992) and fixation index (Fst) with the permutation test, were calculated using the ARLEQUIN 3:01 (Excoffier et al., 2005). NeighborJoining $(\mathrm{NJ})$ method is used to reconstruct phylogenetic relationships among haplotype with MEGA version 4 (Tamura et al., 2007). Haplotype identification and haplotype network construction were based on the NETWORK 4.5.1.6 (Polzin \& Daneshmand, 2004).

\section{RESULTS AND DISCUSSION}

\section{Sequence Variation and Haplotype Distribution}

Nucleotide sequences were obtained from all 51 fish individuals, sequence length varied from 566-936 bp. The length difference was caused by different numbers of tandem repeat segments. Since there was very few signal for population separation in number of tandem repeat segments (Table 1). The tandem repeat segments were removed and the remaining $560 \mathrm{bp}$ sequences were used for subsequent population analysis.

Table 1. Number tandem repeat on giant featherback control region mtDNA

\begin{tabular}{|c|c|c|c|c|c|c|c|c|c|}
\hline \multirow{2}{*}{ Sample } & \multicolumn{9}{|c|}{ Number tandem repeat } \\
\hline & 0 & 1 & 2 & 3 & 4 & 5 & 6 & 7 & 8 \\
\hline Kuto Panjang & 0 & 0 & 0 & 0 & 0 & 0 & 9 & 1 & 0 \\
\hline Sungai Teso & 0 & 0 & 0 & 0 & 0 & 0 & 11 & 0 & 0 \\
\hline Langgam & 0 & 0 & 0 & 0 & 0 & 0 & 9 & 0 & 0 \\
\hline Rantau Baru & 0 & 0 & 0 & 0 & 0 & 0 & 9 & 0 & 0 \\
\hline Kuala Tolam & 0 & 0 & 0 & 1 & 0 & 1 & 6 & 1 & 0 \\
\hline Haplotipe spesiasi & 1 & 0 & 0 & 0 & 1 & 1 & 0 & 0 & 0 \\
\hline Chitala lopis & 0 & 0 & 0 & 0 & 1 & 0 & 0 & 0 & 0 \\
\hline
\end{tabular}

There are $104 \mathrm{bp}$ have not yet reported (in the position 16,143-16,247). Detail information on genetic data dan sampling locations (samples code, locations, and samples size) presented in Table 2.

Result analysis from 48 fish specimens in Kampar River, reveal the existence of 8 haplotypes which formed from 10 variable sizes and 3 speciation haplotypes (the very different Kampar River's giant featherback haplotypes formed by more than 118 variables site) identified from 3 specimen Kampar River's giant featherback.

Haplotypes composition and the position of bp variation of Kampar River's giant featherback based on control region mtDNA presented in Table 3 and 4. Among the 8 haplotypes, two haplotypes shared in different samples (shared), 1 haplotype is found in all sample locations; another six are unique of haplotypes. Kutopanjang reservoir sample has 1 site 
specific haplotype; meanwhile Kuala Tolam has 5 site specific haplotypes. Speciation haplotypes were found in Langgam, Rantau baru, and Kuala
Tolam samples. The haplotype distribution map is shown in Figure 1.

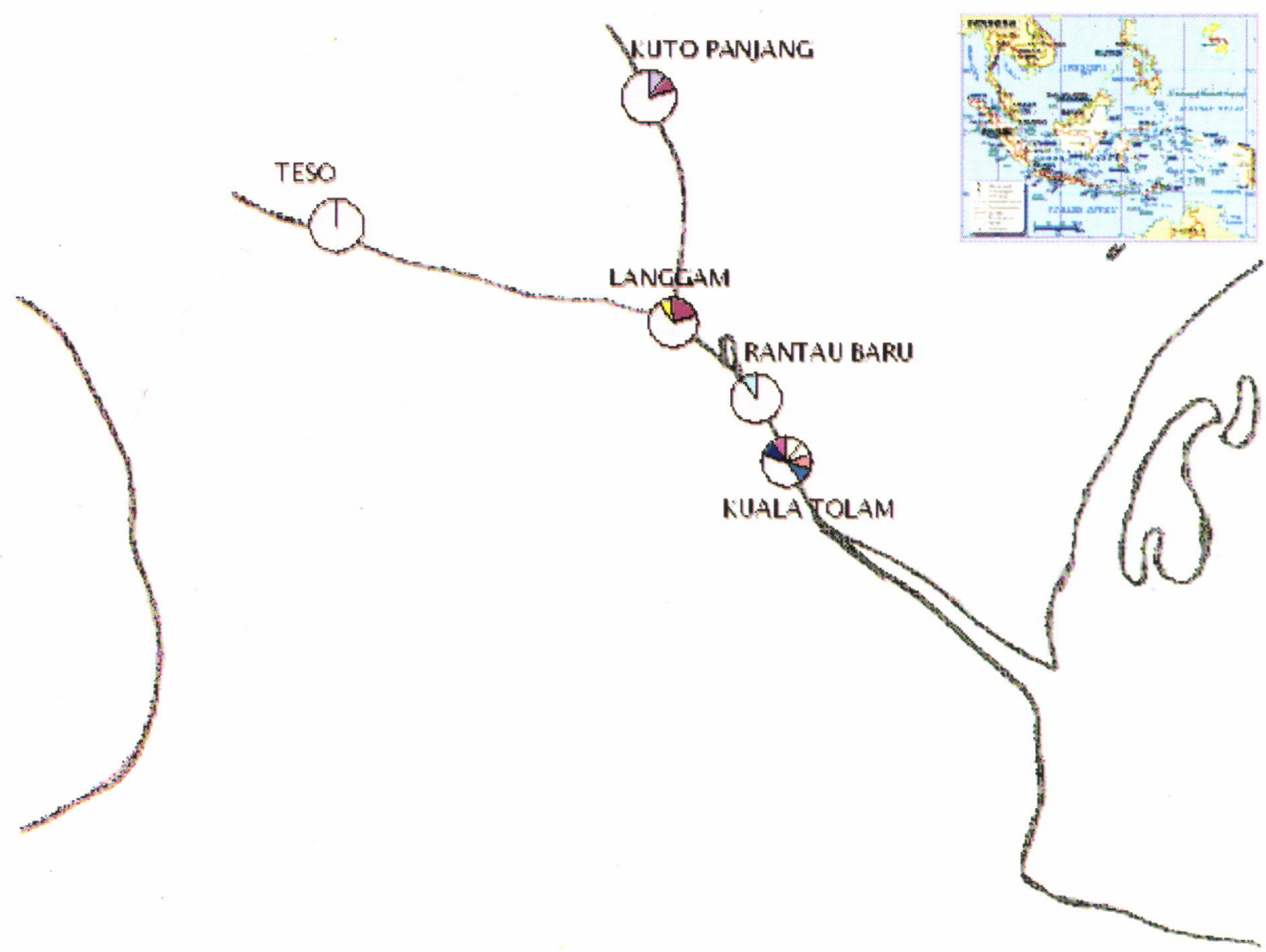

Figure 1. The haplotype distribution of giant featherback in Kampar River base on control region mtDNA. 


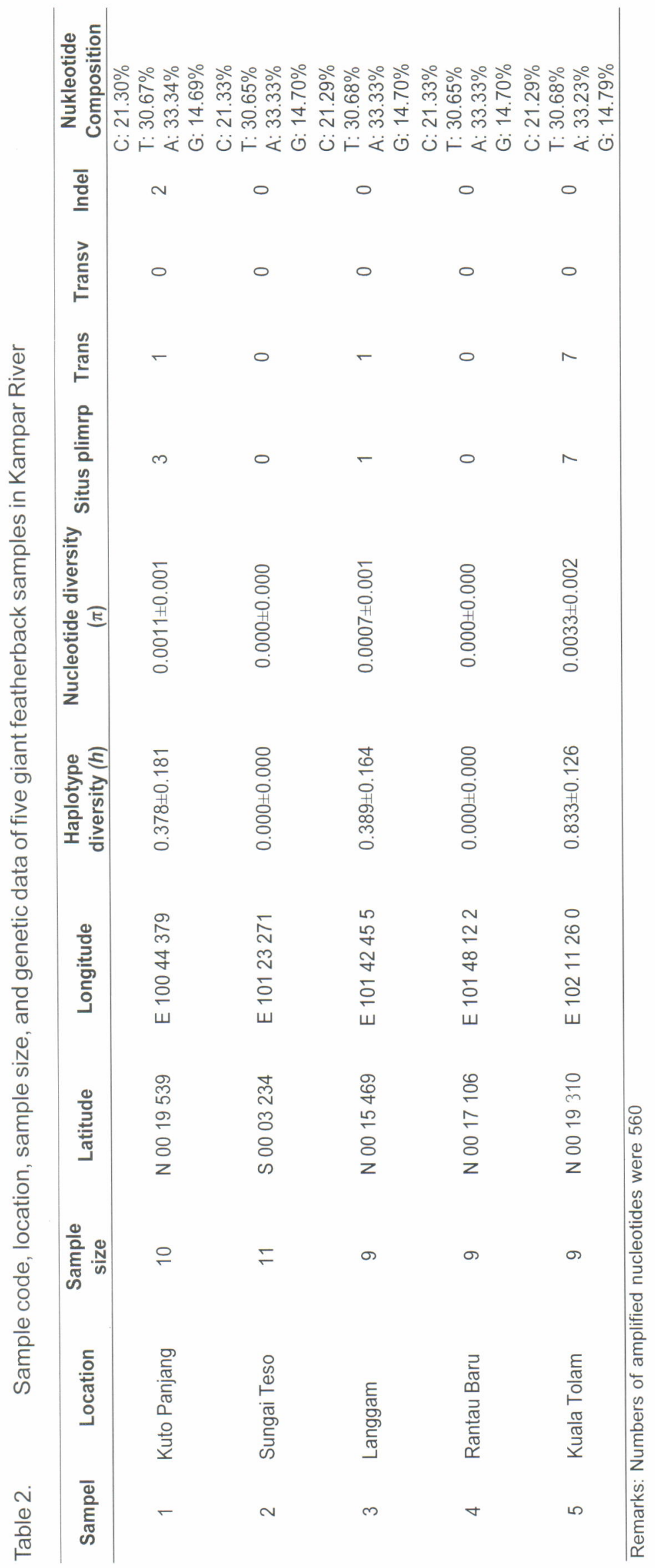




\begin{tabular}{lccccccccccc}
\hline & \multicolumn{10}{c}{ Haplotype } \\
\cline { 2 - 11 } & $\mathbf{1}$ & $\mathbf{2}$ & $\mathbf{3}$ & $\mathbf{4}$ & $\mathbf{5}$ & $\mathbf{6}$ & $\mathbf{7}$ & $\mathbf{8}$ & GG 10 & KT 16 & Total \\
\hline Kuto Panjang & 1 & 1 & - & - & - & - & - & 8 & - & - & - \\
Sungai Teso & - & - & - & - & - & - & - & 11 & - & - & - \\
Langgam & - & 2 & - & - & - & - & - & 7 & 1 & - & - \\
Rantau Baru & - & - & - & - & - & - & - & 9 & - & - & 1 \\
Kuala Tolam & - & - & 1 & 1 & 1 & 1 & 1 & 4 & - & 1 & - \\
\hline
\end{tabular}

Tabel 4.

Position of bp variation of Kampar River giant featherback base on control region mtDNA

\begin{tabular}{lllllllllll}
\hline & $\mathbf{1}$ & $\mathbf{1}$ & $\mathbf{1}$ & $\mathbf{1}$ & $\mathbf{1}$ & $\mathbf{1}$ & $\mathbf{1}$ & $\mathbf{1}$ & $\mathbf{1}$ & $\mathbf{1}$ \\
\multicolumn{1}{c}{ Haplotype } & $\mathbf{5}$ & $\mathbf{5}$ & $\mathbf{5}$ & $\mathbf{5}$ & $\mathbf{5}$ & $\mathbf{5}$ & $\mathbf{6}$ & $\mathbf{6}$ & $\mathbf{6}$ & $\mathbf{6}$ \\
& 7 & $\mathbf{7}$ & $\mathbf{7}$ & $\mathbf{8}$ & $\mathbf{8}$ & $\mathbf{8}$ & $\mathbf{0}$ & $\mathbf{0}$ & $\mathbf{0}$ & $\mathbf{1}$ \\
& $\mathbf{7}$ & $\mathbf{7}$ & $\mathbf{8}$ & $\mathbf{1}$ & $\mathbf{5}$ & $\mathbf{6}$ & $\mathbf{2}$ & $\mathbf{8}$ & $\mathbf{8}$ & $\mathbf{6}$ \\
\hline Chitala lopis & $\mathbf{5}$ & $\mathbf{6}$ & $\mathbf{9}$ & $\mathbf{8}$ & $\mathbf{3}$ & $\mathbf{3}$ & $\mathbf{9}$ & $\mathbf{7}$ & $\mathbf{9}$ & $\mathbf{9}$ \\
Haplotype 1 & $\mathrm{T}$ & $\mathrm{A}$ & $\mathrm{C}$ & $\mathrm{A}$ & $\mathrm{A}$ & $\mathrm{C}$ & $\mathrm{A}$ & $\mathrm{C}$ & $\mathrm{A}$ & $\mathrm{G}$ \\
Haplotype 2 & $\mathrm{T}$ & $\mathrm{A}$ & - & - & - & - & - & - & - & - \\
Haplotype 3 & - & - & $\mathrm{T}$ & - & - & - & - & - & - & - \\
Haplotype 4 & - & - & - & $\mathrm{G}$ & - & $\mathrm{T}$ & - & - & - & - \\
Haplotype 5 & - & - & - & $\mathrm{G}$ & $\mathrm{G}$ & - & - & - & - & - \\
Haplotype 6 & - & - & - & $\mathrm{G}$ & - & - & - & - & - & - \\
Haplotype 7 & - & - & - & - & - & - & $\mathrm{G}$ & - & - & - \\
Haplotype 8 & - & - & - & - & - & - & - & $\mathrm{T}$ & $\mathrm{G}$ & - \\
\hline
\end{tabular}

Genetic Diversity and Population Genetic Differences

Variation of D-Loop sequences among five samples was summarized in Table 1. Samples Kuala Tolam shows the highest amount of haplotype and nucleotide diversity $(h=0.833 \pm 0.126$ and $ð=0.0033 \pm 0.002$ ), meanwhile samples Rantau Baru and Teso show low levels of diversity $(h=0.000 \pm 0.000$; $\delta=0.000 \pm 0.000$ ).

AMOVA Analysis indicates that the proportion of total genetic variation was found within samples $(92.88 \%)$, only $(7.12 \%)$ the variations is found among samples (Table 5), and there is a difference between 5 samples location eventhough the magnitude is small.

Table 5.

Analysis of molecular variance for giant featherback samples in Kampar River

\begin{tabular}{lcccc}
\hline \multicolumn{1}{c}{ Source of variation } & d.f. & Sum of squares & Variance components & Percentage of variation \\
\hline Among populations & 4 & 1,869 & $0.0201 \mathrm{va}$ & 7.12 \\
Within populations & 43 & 11,589 & $0.2670 \mathrm{vb}$ & 92.88 \\
\hline Total & $\mathbf{4 8}$ & $\mathbf{1 3 , 4 5 8}$ & $\mathbf{0 . 2 9 0 1}$ & $\mathbf{1 0 0}$ \\
\hline
\end{tabular}

Fixation Index FST: 0.0711

Fixation index (Fst) and slatkin's genetic distances (d) between paired samples shown in Table 6. These data inform that there is a significant genetic difference (base on 10.000 permutation test) between samples from Kuala Tolam with Kutopanjang Reservoir and Teso site $(F s t=0.1121$ and $F s t=0.0713 ; d=0.126$ and $d=0.0767$ ). Sample between Kutopanjang and Langgam location have the most genetic similar (Fst=0.037), while samples between Kuala Tolam with Teso and Kutopanjang reservoir have most different genetically (Fst=0.1121 and $F s t=0.0713)$. 
Table 6. Fixation index (Fst) (bottom) and genetic distance (above) five samples of giant featherback in Kampar River

\begin{tabular}{lccccc}
\hline & Kutopanjang (1) & River Teso (2) & Langgam (3) & Rantau Baru (4) & Kuala Tolam (5) \\
\hline Kutopanjang & & 0.0101 & 0.000 & 0.000 & 0.0767 \\
Sungai Teso & 0.010 & & 0.1845 & 0.000 & 0.1263 \\
Langgam & -0.037 & 0.156 & & 0.1429 & 0.100 \\
Rantau Baru & -0.011 & 0.000 & 0.125 & & 0.0091 \\
Kuala Tolam & $0.0713^{*}$ & $0.1121^{*}$ & 0.091 & 0.0833 &
\end{tabular}

Remarks: * values were significant on 10.000 permutation test ${ }^{*} \mathrm{P}<0.05$ )

Samples Kuala Tolam seems to be a unique, when the four upper stream samples (Rantau Baru, Langgam, Teso, and Kutopanjang) were grouped and compared to a group consisting of Kuala Tolam samples. The amount of variance between the two groups was a large $24.85 \%$ (Table 7 ). On the contrary when all river samples (Rantau Baru, Kuala Tolam, Langgam, and Teso) were grouped and compared to a group reservoir consisting of Kutopanjang samples. The amount of variance between two groups was a relatively small -6.58 (Table 7 ).

Table 7.

Analysis of molecular variance for giant featherback samples in Kampar River with grouping of population. Populations were Rantau Baru (RB), Langgam (LG), Teso (ST), Kutopanjang (WD), and Kuala Tolam (KT)

\begin{tabular}{|c|c|c|c|c|c|c|}
\hline \multirow[b]{2}{*}{ Population grouping } & \multicolumn{6}{|c|}{ Variance } \\
\hline & $\begin{array}{c}\text { Within } \\
\text { populations }\end{array}$ & $\begin{array}{l}\text { Among populations } \\
\text { within groups }\end{array}$ & $\begin{array}{l}\text { Among } \\
\text { groups }\end{array}$ & $\Phi_{\mathrm{sc}}$ & $\Phi_{\mathrm{ST}}$ & $\Phi_{C T}$ \\
\hline $\begin{array}{l}\text { Upper stream (RB, } \\
\text { LG,ST, and WD) } \\
\text { and Down stream } \\
\text { (KT) }\end{array}$ & 78.61 & -3.46 & 24.85 & -0.046 & $0.214^{*}$ & 0.248 \\
\hline $\begin{array}{l}\text { River (KT, RB, LG, and } \\
\text { ST) and Reservoir } \\
\text { (WD) }\end{array}$ & 96.47 & 10.11 & -6.58 & 0.09484 & $0.03527^{\mathrm{ns}}$ & -0.065 \\
\hline
\end{tabular}

These analysis reveal the existence of two reproduction units of giant featherback in Kampar River; one population was in upper reaches of Kampar River which is representative by samples from Kutopanjang, Rantau Baru, Langgam, and Teso and downstream that is representative by samples from Kuala Tolam. This is apparently due to isolation by distance, that gen flow may be restricted among giant featherback population in Kampar River. The same phenomenon (in which more distant location of the sample the greater the genetic differences) was observed by Takagi et al. (2006) in bronze featherback Notophterus nothopterus in the Mekong River, Thailand (Fst -002-0.08), that genetic similarity in Macrobrachium nipponense is associated with the distance of sample location.

In general, the active movement of adult giant featherback and passive movement of eggs and larvae would accelerate the occurrence of gene flow among populations (Slatkin, 1987). However, the low swimming ability (this could be seen from the shape) of adult giant featherback who live in the standing waters and slow moving of habitat type in the lake, Oxbow marshes, ditches and ponds (Rainboth, 1996) and eggs that are not easily spread out (fish eggs attached to solid submerged vegetation) (Talwar \& Jhingran, 1991), give a consequence, gene flow will be inversely proportional to the sample location.

In this work, giant featherback samples from Kuala Tolam (downstream) are a distinct population, different from the other samples in the upper reaches the Kampar River which is another population. On the management of water resources, it is important to manage each population separately. The results of this study is clearly reveal that presence of two reproductive units of giant featherback in Kampar River water basin are genetically separated. Each giant featherback populations should be managed and evaluated separately for sustainable utilization. 


\section{Phylogeny Reconstruction}

Neighbor-Joining tree Kimura 2 parameter (Figure 2) reconstructed from 24 haplotypes (11 haplotypes Kampar River samples and 13 haplotypes samples as comparison). Base on phylogeny tree, common haplotypes of Kampar River's giant featherback (haplotype 1-8) monophyletic with Chitala lopis. Kampar River's giant featherback were Chitala lopis with the exceptional haplotypes speciation 1 and 2.

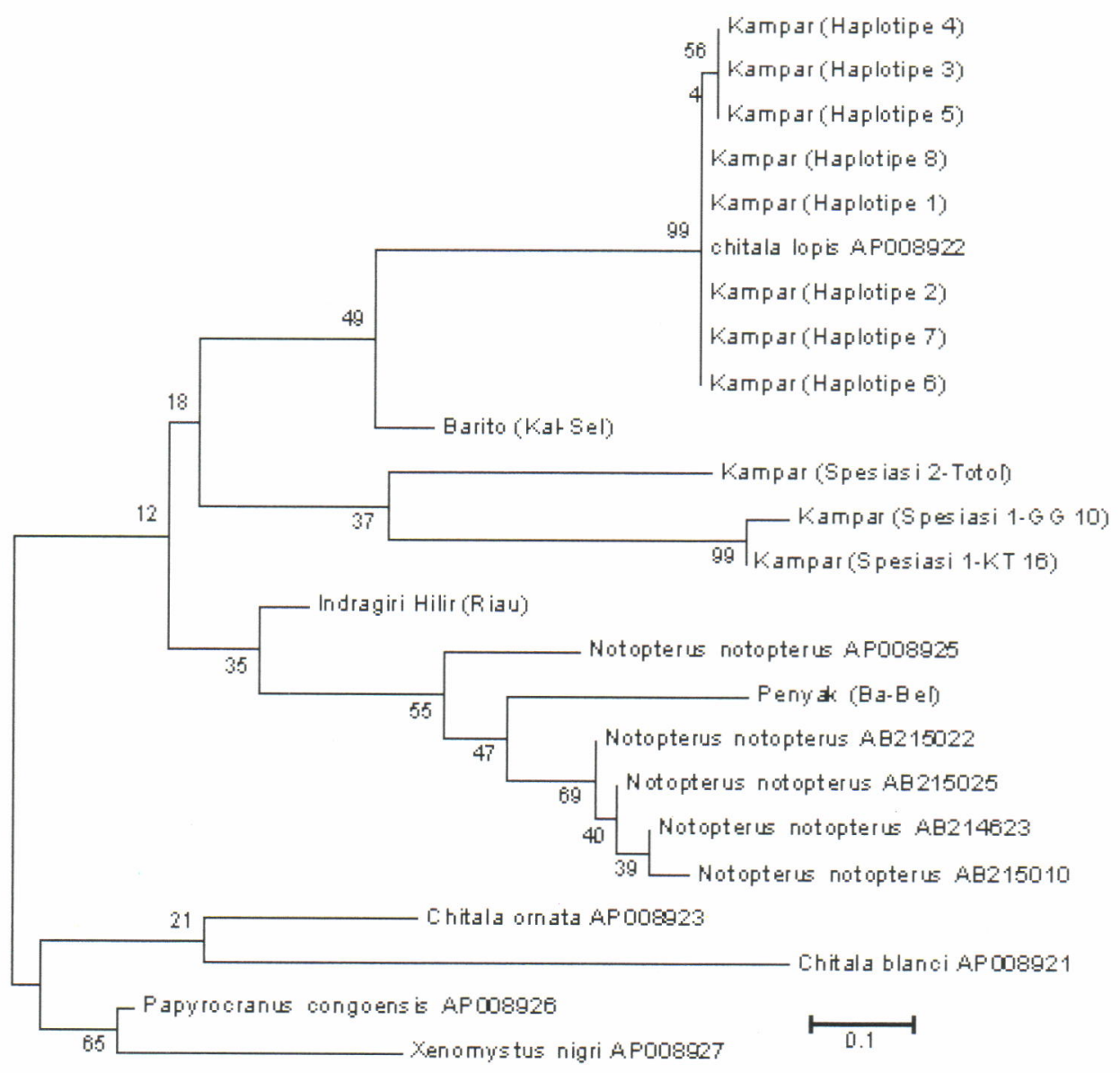

Figure 2. Neighbour-Joining phylogeny Kimura 2 parameter haplotype of giant featherback.

Kampar River giant featherback haplotype speciation 1 form a giant featherback haplotype inhabitant acid waters, found in sampling location that has acid water attributed by black colour water which are Kuala Tolam and Langgam sampling sites. These haplotypes have wider body and bent, black colour and small head (Figure 3).

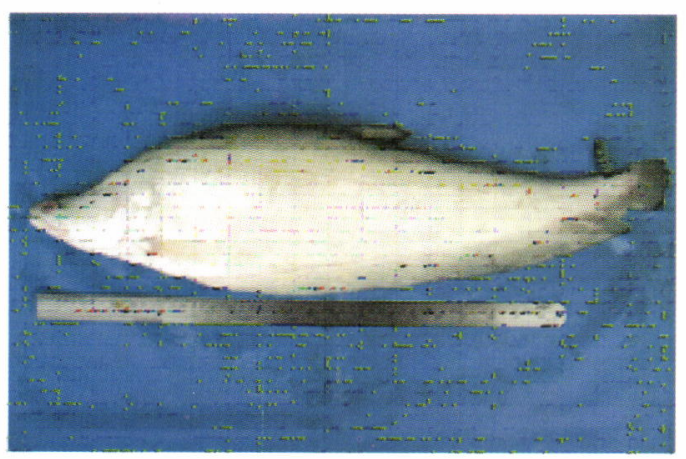

1 (Common form of Kampar River's giant featherbak) 

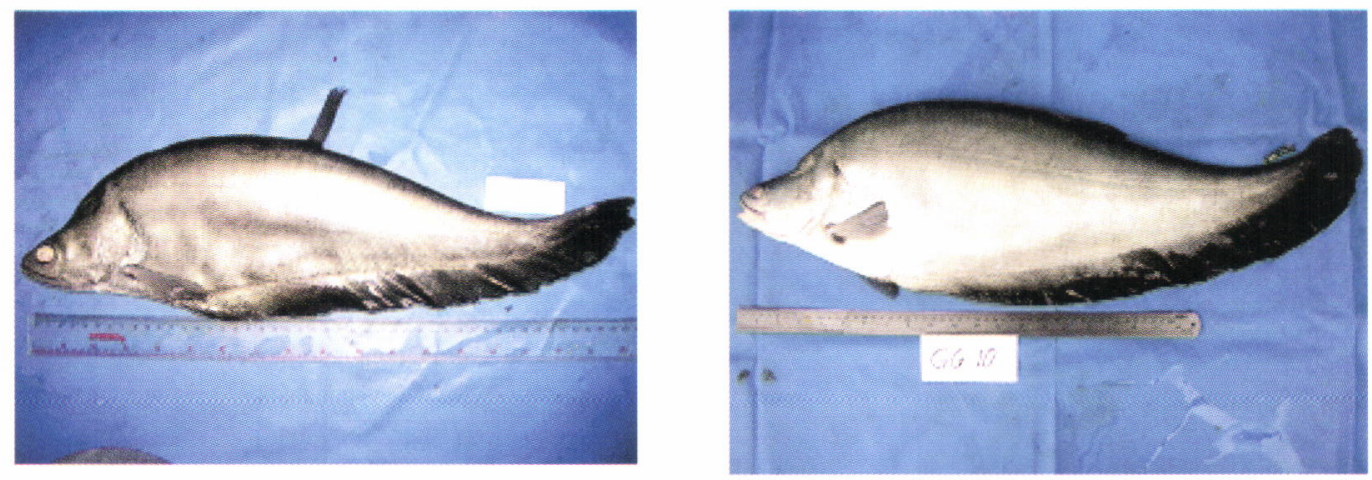

Figure 3. Morphology performance of Kampar River's giant featherback lives in acid water (2 and 3) charachteristic by haplotype speciation 1 .

Kampar River giant featherback haplotype speciation 2 known by local fishermen as Kumbuhan. The size of Kumbuhan can reach more than $30 \mathrm{~kg} /$
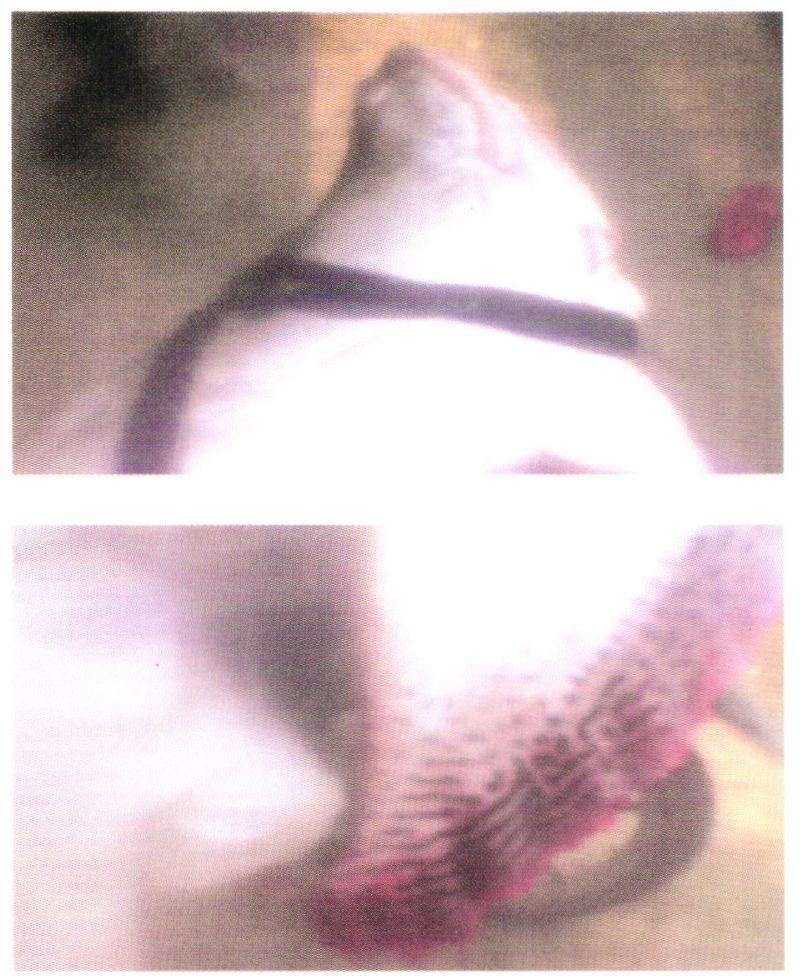

ind. Attributed with red colour and motif pattern in caudal fin, the giant featherback with this size is never reported before (Figure 4).
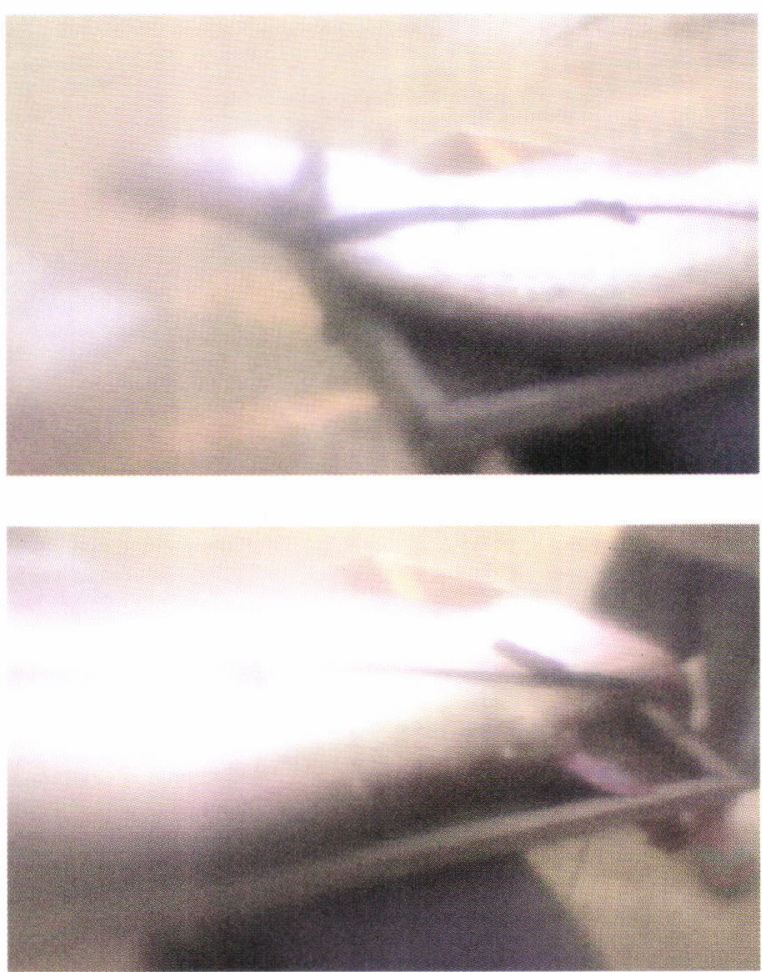

Figure 4. 30

Morphology performance of Kumbuhan, giant featherback that can reaches more than

$\mathrm{kg} /$ ind. attributed with red colour and motif pattern in caudal fin.

Phylogeny tree inform, the existence of genetic structure along the river (Kampar River) and in different river (example Kampar River and Indragiri River). In Kampar River, giant featherback lives in downstream (Kuala Tolam) has a significant genetic difference with the giant featherback that lives in upper reaches of Kampar River (Teso, Rantau Baru, Langgam, and Kutopanjang). However, the genetic structure is not as clearly as another fish, such as Notophterus notopterus. Compared with other rivers,
Kampar River's giant featherbacks have different haplotype properties than Indragiri River (Riau Province), Penyak River (Bangka Belitung Province) and Barito River (South Kalimantan Province).

In order to know ancestral haplotype, haplotype position, and frequency were constructed using haplotype network, sees in Figure 5. Base on network construction, Kampar River's giant featherback has haplotype group ST 03 (which is haplotype 8) this is 
a common haplotype of Kampar River's giant featherback. Then Haplotype 8 undergo differentiation become haplotype 1 (WD 23), haplotype 2 (group of
GG 04), haplotype 6 (KT 11), haplotype 7 (KT 15) and haplotype 5 (KT 01). Haplotype 5 then differentiated become haplotype 3 (KT 20) and haplotype 4 (KT 07).

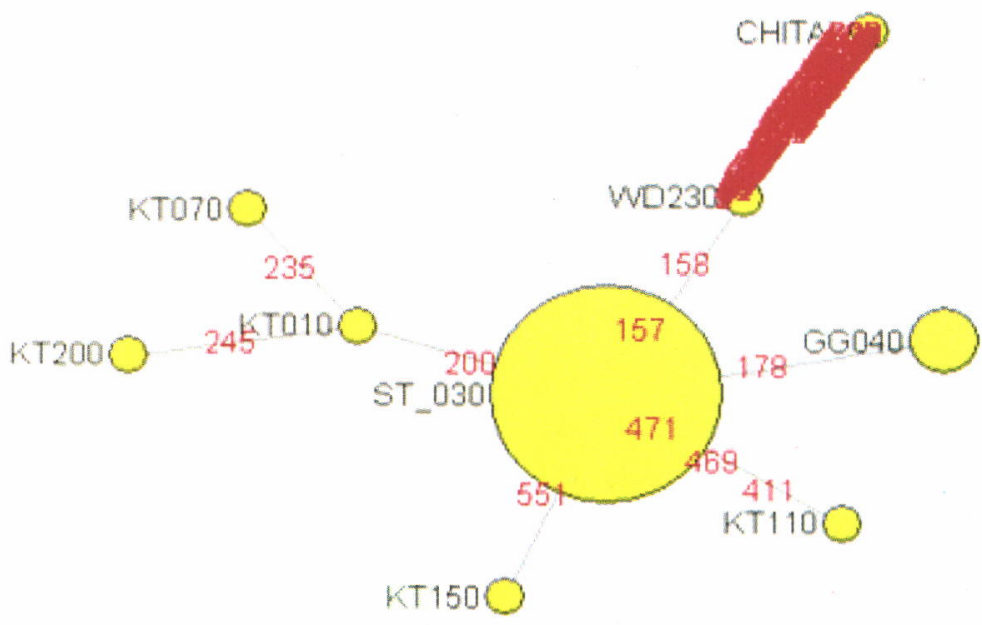

Figure 5. Network constructed of Kampar River's giant featherback.

Genetic polymorphism, from mtDNA prespective determine population health in natural population. As more variety of its mtDNA then the population has more main prime (mother) and more healthy the population. Base on this statement Kuala Tolam samples are the healtiest population, they have 7 mother ( 7 haplotype), include haplotype speciation 1. On the contrary, giant featherback from Teso samples, they are the lowest population health because they only have 1 haplotype.

\section{CONCLUSIONS}

1. There are 8 haplotypes of Kampar River's giant featherback which formed from 10 variable sizes and 3 speciation haplotypes ( very different Kampar River's giant featherback haplotypes formed by more than 118 variables site) identified from 3 specimen of Kampar River's giant featherback. 104 bp have not yet reported (in the position 16,143$16,247)$.

2. The existence of genetic structure along the river (Kampar River) and in different river (example Kampar River and Indragiri River). In Kampar River, giant featherback living in downstream (Kuala Tolam) has a significant genetic difference with the fish that lives in upper reaches of Kampar River (Rantau Baru, Langgam, Teso, and Kutopanjang). Kampar River's giant featherbacks have different haplotype properties than Indragiri River (Riau Province), Penyak River (Bangka Belitung

\section{Province) dan Barito River (South Kalimantan} Province).

3. Samples Kuala Tolam shows the highest amount of haplotype and nucleotide diversity ( $h=0.833 \pm 0.126$ and $\delta=0.0033 \pm 0.002$ ), meanwhile samples Rantau Baru and Teso show low levels of diversity $(h=0.000 \pm 0.000 ; \partial=0.000 \pm 0.000)$.

\section{ACKNOWLEDGMENT}

This paper was prepared in the framework of research genetic resources management of Indonesia's in endangered fish (giant featherback/ Chitala lopis) through conservation and enhancement of genetic diversity in Research Institute of Inland Fisheries funded by Agency of Marine and Fisheries Research of the Ministry of Marine Affair and Fisheries, Indonesia in the F.Y. 2009. To whom the authors would like to express gratitude without which this paper would not materialized.

\section{REFERENCES}

Anonymous. 2003. (In Indonesia). Giant featherback, the suffering night dancer. Kompas. September $17^{\text {th }}$.

Provincial Marine Affair and Fishes Services. 2008. (In Indonesia). Statistic Capture Fisheries of Riau Province. Pekan Baru. Dinas Perikanan dan Kelautan. Provinsi Riau. 
Directorate General of Fisheries. 2000. (In Indonesia) Statistic of Indonesia Fisheries. Misnistry of Agriculture. Jakarta.

Excoffier, L., G. Laval, \& S. Schneider. 2005. Arlequin ver. 3.0: An integrated software package for population genetics data analysis. Evolutionary Bioinformatic Online. (1): 47-50.

Excoffier, L., P. E. Smouse, \& Quattro. 1992. Analysis of molecular variance inferred from metric distance among haplotypes: Application to human mitochondrial DNA restriction data. Genetics. 131 (2): 479-491.

Kottelat, M., S. N. Kartikasari, A. J. Whitten, \& S. Wirjoatmodjo. 1993. Freshwater Fishes of Western Indonesia and Sulawesi. Ed. Dua Bahasa. Periplus Editions Limited. Jakarta. 221 pp.

1997. Freshwater Fishes of Western Indonesia and Sulawesi. Ed. Dua bahasa. Periplus Editions and Emdi Project Indonesia. Jakarta. 293 pp.

Madang, K. 1999. (In Indonesia). Habitat morphology and genetic diversity of Notophteridae in South Sumatera inland water. Thesis. Bogor. Garaduates Program. Bogor Agricultural University.

MnO. 2005. (In Indonesia). Food for Eyes Protection. http://www.promosi kesehatan.com/tips?nid=74.

Nei, M. \& F. Tajima. 1981. DNA polymorphism detextable by restriction endonucleases (J). Genetics. 97 (1): 145-163.

Nei, M. 1987. Melecular Evolutionary Genetics. New York. Colombia University Press.

Polzin, T. \& S. V. Daneshmand. 2004. Steiner (MP) algorithm. Fluxus Technology. http://www.fluxustechnology.com/.

Rainboth, W. J. 1996. Fishes of the Cambodian Mekong. FAO. Rome.
Slatkin, M. 1987. Gene flow and geographic structure of natural populations. Science. (236): 787-792.

Sunarno, M. T. D. 2002. (In Indonesia). Saves giant featherback Plasma nutfah. Warta Penelitian Perikanan Indonesia. 8 (4): 2-6.

Sunarno, M. T. D., A. Wibowo, \& Subagja. 2007. (In Indonesia) Identification of three group giant featherback (Chitala lopis) in Tulang Bawang River, Kampar, and Kapuas base on biometric approach. Jurnal Penelitian Perikanan Indonesia. (4): 46-50.

Takagi, A. P., S. Ishikawa, T. Nao, S. Hort, M. Nakatani, M. Nishida, \& H. Kurokura. 2006. Genetic differentiation of the bronze featherback Notopterus notopterus between Mekong River and Tonle Sap Lake population by mitochondrial DNA analysis. Fisheries Science. (72): 750-754.

Talwar, K. P. \& A. G. Jhingran. 1991. Inland Fishes of India and Adjacent Countries. Oxford \& IBH. New Delhi.

Tamura, K., J. Dudley, M. Nei, \& S. Kumar. 2007. MEGA4: Molecular Evolutionary Genetics Analysis (MEGA) software version 4.0. Molecular Biology and Evolution. 10.1093/molbev/msm092.

Thompson, J. D., T. J. Gibson, F. Plewniak, F. Jeanmougin, \& D. J. Higgins. 1997. The clustal X windows interface: Flexible strategies for multiple sequences alignment aided by quality analysis tool. Nucleic Acid Res. 25 (24): 4,876-4,882.

Wibowo, A., M. T. D Sunarno, \& Subagja. 2008a. (In Indonesia). Identification stock structure of giant featherback belida (Chitala spp.) and its implication on management natural population. Jurnal Penelitian Perikarian Indonesia. (3): 11-17.

2008b. (In Indonesia). Diversity status of giant featherback (Chitala spp.) in Tulang Bawang River base on morphometric characters and index of asymmetric fluctuating. Jurnal Penelitian Perikanan Indonesia. (3): 1-9. 